\title{
Konsep Falsafah Penghukuman dalam Islam
}

\section{Hamdani ${ }^{1}$}

${ }^{1}$ Dosen Fakultas Hukum Universitas Malikussaleh

\begin{abstract}
Abstrak
Hikmah daripada penghukuman dalam Islam adalah untuk menegah manusia dan menahan manusia daripada mendekati perbuatan jenayah, memelihara masyarakat daripada kefasadan, dan menyucikan daripada dosa dan noda. Tulisan ini bertujuan untuk melihat falsafah penghukuman dalam Islam. Adapun falsafah penghukuman dalam Islam adalah sebagai pembalasan, selain daripada itu hukuman juga dapat memberi kesan yang ditinggalkan oleh hukuman ke atas penjenayah yang memberi pengajaran, memperbaiki dan menghalang seseorang daripada melakukan jenayah. Selain daripada itu hukuman juga untuk membersihkan dosa penjenayah dan menyelamatkannya daripada azab di akhirat. Selain daripada itu penghukuman juga bertujuan untuk menimbulkan rasa gerun kepada orang awam akibat hukuman yang dikenakan kepada penjenayah. Ia merupakan suatu kaedah pencegahan dan pendidikan kepada orang ramai agar tidak terlibat di dalam jenayah. Hukuman yang dilaksanakan juga bertujuan untuk mewujudkan rasa keadilan kepada manusia bagi menjamin kebahagiaan hidup, keadilan dalam menjalankan hukuman sehingga akan menghasilkan kemakmuran dan kedamaian dalam masyarakat.
\end{abstract}

Katakunci: konsep falsafah, Penghukumanl, Islam. 


\section{PENDAHULUAN}

Dalam tulisan ini akan memberi penerangan secara ringkas mengenai konsep falsafah penghukuman dalam Islam. Tulisan ini akan membahas mengenai maksud dan tujuan penghukuman dalam Islam sehingga mencapai matlamat dan tujuan daripada penghukuman itu sendiri. Adapun falsafah penghukuman dalam Islam adalah bertujuan sebagai pembalasan bagi sipelaku, pencegahan baik bagi sipelaku maupun masyarakat atau sebagai pengendalian social. Selain daripada itu hukuman juga sebagai perwujudan keadilan dan penghapusan dosa.

Satu hal yang terpenting dalam pelaksanaan hukuman jenayah iaitu hanya terhadap orang yang melakukan jenayah sahaja yang dihukum dengan hukuman keseksaan sesuai dengan ketentuan undang-undang, supaya masyarakat umum terlindungi daripada perbuatan jenayah sehingga ketentraman awam terkawal. Oleh sebab itu tiada alasan bagi pihak lain untuk takut akan pelaksanaan hukum jenayah Islam, oleh sebab kerasnya hukuman yang dikenakan terhadap penjenayah. Kerasnya hukuman tersebut disebabkan oleh kerana Islam memandang serius perkara itu, maka terhadap pesalah yang melakukan hukuman seperti kesalahan hudud, akan dikenakan hukuman yang keras sesuai dengan kesalahannya. Demikian pula terhadap hukuman qisas, akan diberikan hukuman sepadan dengan kesalahan yang dilakukan atau akan dikenakan diyat dan kemaafan. Sedangkan hukuman ta'zir dilaksanakan demi menjaga kemaslahatan umat.

\section{METODE PENELITIAN}

Adapun jenis penelitian ini adalah penelitian dokrinal atau penelitian normative (normative law research) yaitu suatu penelitian yang mengkaji dan melihat konsep dan falsafah penghukuman dalam Islam. Dengan menggunakan tipe penelitian deskritif. Sumber data didapat melalui studi kepustakaan. Analisis data melalui analisis data kualitatif.

\section{PEMBAHASAN}

3.1 Filsafah Penghukuman dalam Islam

Penghukuman dalam Islam merupakan kebaikan kepada masyarakat dan alam sejagat, ianya juga merupakan rahmat dan anugerah yang meliputi kepada semua makhluk, tanpa mengira pangkat dan kedudukan, ia juga tampa mengenal puak dan kaum (bangsa). Pemberian hukuman dalam Islam mempunyai falsafah dan 
konsep tersendiri yang membawa rahmat kepada seluruh alam. Dalam hal penjatuhan hukuman, menurut Abd al-Qadir 'Audah, yang menjadi falsafah penghukuman dalam Islam meliputi, konsep keadilan, konsep pencegahan dan konsep pemeliharaan nilai-nilai murni dalam masyarakat. (Audah, 1994: 609)

Adapun hikmah daripada penghukuman dalam Islam adalah untuk menegah manusia dan menahan manusia daripada mendekati perbuatan jenayah, memelihara masyarakat daripada kefasadan, dan menyucikan daripada dosa dan noda. Menurut Ibn Taymiyyah, diantara rahmat Allah SWT. iaitu mensyariatkan hukuman jenayah yang berlaku antara manusia, sebahagian mereka ke atas sebahagian yang lain pada jiwa, tubuh badan, harta benda, kehormatan, pembunuhan, pencederaan, menuduh zina (qadhab), mencuri. Oleh yang demikian maka Allah S.W.T. telah menentukan bentuk-bentuk tegahan supaya dapat menahan melakukan daripada melakukan jenayah yang merupakan matlamat hukuman dan mensyariatkan hukuman dalam bentuk yang sebaik-baiknya.

Adapun penghukuman dijatuhkan yang mengandungi kemaslahatan, tegahan dan pembasmian, di samping itu tidak melampaui kadar yang sepatutnya ditanggung oleh penjenayah daripada tegahan itu. (al-Zuhaili, 2011, 238) Dalam pemberian hukuman tersebut Allah S.W.T. mensyariatkan kepada mereka tentang hukuman tersebut dengan memastikan nama dan sifatnya termasuk dalam hikmah dan rahmat-Nya, kelembutan, keehsanan dan keadilan-Nya agar menghilangkan bala atau celaka dan melenyapkan kezaliman dan permusuhan sehingga semua insan berpuas hati dengan apa yang dikurniakan oleh Malik dan Khaliknya. Dengan itu sehingga manusia tidak akan sewenangwenangnya merampas hak orang lain. (al-Zuhaili, 2011, 238)

Selain daripada itu dalam Islam dikenal juga dengan istilah 'uqubah yang merupakan perkataan daripada bahasa Arab yang berasal daripada kata perbuatan 'aqaba yang bermaksud pembalasan atau hukuman. Terdapat sebahagian fuqaha yang menggunakan perkataan 'iqab, yang merujuk kepada makna yang serupa. Selain itu terdapat juga fuqaha yang membezakan maksud 'uqubah dengan 'iqab. Mereka berpendapat bahawa 'uqubah khusus dalam bentuk pembalasan atau hukuman di dunia. Manakala 'iqab iaitu pembalasan atau hukuman yang akan diterima nanti di akhirat. Sedangkan 'uqubah dalam skop yang lebih luas bolehlah 
diertikan sebagai apa-apa juga bentuk hukuman yang diperuntukkan bagi pelbagai kesalahan, sama ada kesalahan akibat melanggar larangan agama ataupun kesalahan akibat tidak melakukan perkara-perkara yang telah diwajibkan untuk melaksanakannya. (Bahnasy, 2008: 2)

Tujuan penghukuman dalam Islam adalah untuk mengawal lima tujuan mutlak yang menjadi tunjang kesejahteraan dan keamanan seluruh umat manusia dan seluruh dunia. Lima perkara mutlak yang dimaksud tersebut adalah mengawal agama, mengawal jiwa, mengawal akal fikiran, mengawal harta benda, dan mengawal keturunan. (Al-Jazairi, 2011:480-82) Dengan terkawalnya kelima-lima perkara asas tersebut maka barulah keselamatan pribadi, keluarga, masyarakat, negara dan dunia terjamin adanya.

Tujuan-tujuan tersebut bukanlah rekaan manusia sematamata melainkan perintah-perintah dan larangan-larangan Allah yang tidak berubah dan tidak boleh dipinda. Bagi mengawal keturunan manusia supaya suci dan terjaga dikenakan hukuman sebat seratus kali dan rejam sampai mati kepada pelaku zina. Bagi mengawal keselamatan akal fikiran dikenakan hukuman 40 kali sebat ataupun 80 kali sebat ke atas pem- inum khamar dan sejenisnya. (Bukhari, 2009: 30)Bagi mengawal maruah atau nama baik seseorang dikenakan hukuman sebat sebanyak 80 kali ke atas orang yang menuduh perempuan baikbaik dengan tuduhan zina tampa membawa empat orang saksi atau dinamakan dengan kesalahan qazaf. Bagi menjaga keselamatan nyawa seseorang, dikenakan hukuman bunuh balas ke atas pembunuh yang sengaja. Bagi mengawal agama supaya terjamin kemurniannya, dikenakan hukuman bunuh kepada orang yang murtad selepas diminta taubat akan tetapi ianya masih juga tetap berdegil. Kemudian bagi menjaga keselamatan negara diperintah untuk memerangi pemberontakpemberontak yang mengancam ketenteraman awam dan keselamatan pemerintah yang adil. (Said, 2000: 918)

Pada asasnya, hukuman yang dikenakan ke atas pesalah dalam undang-undang jenayah Islam berfungsi untuk melindungi individu dan masyarakat daripada sebarang anasir jahat serta menyelamatkan mereka daripada kebinasaan. Dalam masa yang sama hukuman tersebut juga dapat memberikan pengajaran agar tidak mengulangi lagi melakukan perbuatan jahat yang telah dilakukan. Sedangkan hukuman bunuh, maka ianya akan menjadi pelajaran 
kepada orang ramai supaya tidak melakukan perbuatan jenayah yang membawa kepada hukuman bunuh tersebut. Hukuman dapat menghalang orang ramai atau individu melakukan jenayah, dan hukuman juga akan mendorong manusia agar supaya taat kepada Allah. Untuk lebih jelasnya hukuman itu mempunyai tujuan sebagaimana yang akan dihuraikan di bawah ini.

\subsection{Hukuman sebagai Pembalasan}

Pembalasan bertujuan memberi ganjaran kepada sesiapa yang melakukan ketaatan dengan pahala dan kebaikan, dan juga azab siksa kepada sesiapa yang melakukan kemungkaran dan kejahatan. Tujuan daripada dikenakan hukuman adalah untuk pembalasan terhadap pesalah atau boleh disebut juga dengan 'balas dendam' yang berasaskan konsep semulajadi manusia yang menginginkan kejahatan dibalas dengan kejahatan. Konsep ini mempunyai asas yang kukuh berasaskan kepada prinsip agama dan keadilan sejagad. Dalam Islam, unsur hukuman di dalam hukuman jenayah dinyatakan secara jelas dalam al-Qur'an seperti berikut yang terjemahannya:

"Lelaki yang mencuri dan wanita yang mencuri, maka potonglah (pergelangan) tangan (kanan) mereka sebagai satu pembalasan terhadap apa yang telah mereka kerjakan dan sebagai seksaan daripada Allah. Allah Maha Berkuasa, lagi Maha Bijaksana". Qs. Almaidah: 38)

Dalam Islam ditegaskan bahawa pembalasan itu mestilah setimpal dan sepadan dengan apa yang dilakukan, umpamanya dalam hukuman qisas orang yang membunuh dengan sengaja tanpa hak akan dikenakan qisas iaitu dibunuh balas sebagai balasan atas perbuatannya. Hukuman itu sendiri adalah pembalasan yang dikenakan ke atas penjenayah kerana mencerobohi kepentingan orang lain. Unsur pembalasan akan dapat mengubat, menghilangkan rasa dendam dan menuntut bela oleh pihak yang disakiti, kerana pesalah telah membayar gantirugi dalam bentuk hukuman yang diterima dari pengadilan ke atasnya. (Audah, 1994:609)

Mengenai pembalasan ini, apabila dilihat dari sudut kesannya ke atas pesalah maka dapat berupa, jika pembalasan itu ditujukan langsung kepada diri pesalah sama ada terhadap nyawanya atau tubuh badannya maka pembalasan ini disebut dengan uqubah badaniyyah. Manakala pembalasan yang ditujukan kepada jiwanya, yang menyebabkan pesalah itu tersiksa perasaannya, maka hal ini dinamakan dengan uqubah nafsiyyah, dan apabila pembalasan itu 
yang membabitkan harta benda pesalah seperti pembayaran diyat, maka pembalasan ini dinamakan dengan uqubah maliyyah. Adapun pembalasan yang menyekat kebebasan pesalah, seperti tindakan mengurung pesalah, dinamakan dengan uqubah muqayadah (Yaacob, 2000: 177-197). Adapun tujuan daripada pembalasan ini pada asasnya adalah untuk kebaikan, bukan penderitaan. Hal ini juga bermakna pembalasan dapat menghalang daripada pihak mangsa dari melakukan pembalasan sendiri yang dapat mewujudkan jenayah yang lain.

Bagi mencapai tujuan tersebut, maka setiap penjenayah akan dijatuhi hukuman yang sesuai dengan kesalahan yang dilakukannya. Terdapat berbagai bentuk hukuman yang berbezabeza yang boleh dikenakan ke atas penjenayah. Hukuman yang berbeza ini akan dikenakan sesuai dengan perbuatan jenayah yang dilakukan oleh penjenayah. Hukuman yang berbeza berasaskan kesalahan yang berbeza-beza supaya pembalasan yang dibuat itu adil dan sesuai dengan kesalahan yang diperbuat. Sebagai contoh, kesalahan membunuh akan dibalah dengan hukuman yang setimpal iaitu hukuman bunuh, demikian juga kesalahan keced- eraan akan dibalas dengan kecederaan dan lain-lain.

Hukuman yang setimpal menjadi dasar syarat keseksaan dalam Islam yang mengajar pesalah agar menginsafi kesalahan diri dan kembali ke jalan yang benar. Selain itu, hukuman juga dapat membentuk sifat mulia dan terpuji kerana menjauhi perbuatan yang dilarang dan melakukan amalan yang disuruh. Sudah menjadi lumrah manusia tidak akan berubah hanya dengan mendengar katakata nasehat sahaja, oleh itu maka terhadap pesalah perlu dilakukan sesuatu yang boleh memberi peringatan dan menghalangnya daripada melakukan perbuatan jahat. Dan peringatan tersebut dapat dilakukan dengan memberi hukuman yang setimpal kepada pesalah yang melakukan jenayah. (Rawi, 2007: 24) Pemberian hukuman yang setimpal kepada penjenayah merupakan satu langkah yang wajar bagi memberi kesedaran baik kepada penjenayah itu sendiri mahupun kepada masyarakat awam, sehingga masyarakat menyadari perkara-perkara yang dilarang sepatutnya dijauhi bukannya didekati.
3.3. Hukumaan sebagai Pencegahan jinayat
Kegunaan hukuman Syariah boleh memberikan kesan pengha- lang, baik bagi pesalah itu sendiri 
mahupun orang-orang yang melihat hukuman tersebut dijatuhkan kepada penjenayah, sehingga ia tidak berani lagi mengulangi melakukan perbuatan jenayah tersebut. Tujuan daripada hukuman jenayah yang lain adalah untuk mencegah perbuatan jenayah dengan menimbulkan rasa serik kepada penjenayah tersebut akibat keperitan hukuman yang dikenakan kepadanya. Matlamat ini dapat dicapai bergantung kepada individu penjenayah terbabit serta kepada bentuk dan berat hukuman yang dikenakan pada pelaku tindak pidana.

Dalam penjatuhan hukuman, jika pesalah tersebut merasai keperitan hukuman tersebut, maka dengan sendirinya hukuman tersebut akan mencegah dirinya dari mengulangi melakukan perbuatan jenayah yang sama atau jenayah yang lain. Dalam perundangan Islam, pencegahan ini disebut dengan pencegahan secara khas kepada diri pesalah. Pencegahan ini pula bertindak untuk mencegah diri pesalah daripada melakukannya lagi pada masa yang akan datang. Sebagaimana yang dinyatakan oleh al-Mawardi, peruntukan hukuman hudud dan qisas adalah untuk pencegahan bagi diri pesalah sekiranya pesalah tersebut masih hidup dan menjadi penghalang bagi orang lain untuk mengikutinya sekiranya pelakunya telah dihukum mati. Seterusnya al-Mawardi berpendapat bahawa penjenayah yang telah mati kerana dihukum tidak dapat dicegah lagi, tetapi hukuman ke atasnya itu akan mencegah orang lain yang masih hidup daripada melakukan perbuatan jenayah. (Samuri, 2012: 131-142)

Karena inilah terdapat sesetengah jenayah yang dikenakan hukuman berat seperti penjara dalam tempoh yang lama, kemudian ada juga yang dikenakan hukuman sebatan. Namun demikian keberkesanan hukuman sebagai pencegahan kepada penjenayah agak sukar untuk dinilai. Kerapkali kita mendengar orang yang pernah dihukum kemudian ia mengulangi melakukan perbuatan jenayah yang sama atau jenayah yang lain. Malah sikap masyarakat kita pada masa kini yang menilai serong kepada banduan buat selamalamanya turut menghalang hasrat mereka untuk kembali ke pangkal jalan.

Di dalam Islam, hukuman yang ditetapkan adalah pelbagai dan sesuai dengan jenayah yang dilakukan, bahkan ada hukuman yang dikenakan sifatnya kekal, misalnya hukuman potong tangan ke atas jenayah pencurian. Seseorang yang telah dihukum potong tangan oleh sebab melakukan kes curi, selazimnya akan merasa gerun untuk 
melakukan jenayah tersebut oleh sebab tangannya yang kedua untuk melakukan jenayah yang sama. Begitu juga dalam kes zina, pesalah yang telah dikenakan hukuman sebat, sebab melakukan zina akan serik untuk mengulangi perbuatannya selepas berasa malu sebab dihukum disebat dihadapan khalayak ramai.

\subsection{Hukuman Menimbulkan Efek Jera pada Pelaku Jinayat}

Tujuan hukuman jenayah yang ketiga adalah untuk menimbulkan rasa gerun kepada orang awam akibat hukuman yang dikenakan kepada penjenayah. Dalam hal ini, hukuman menjadi suatu amaran kepada semua lapisan masyarakat agar tidak terlibat di dalam kancah jenayah. Ia merupakan suatu kaedah pencegahan dan pendidikan kepada orang ramai agar tidak terlibat di dalam jenayah. Secara umum, hukuman dalam Islam bertujuan untuk mencegah masyarakat daripada melakukan jenayah. Ini dapat dilihat pada hukuman hudud yang sememangnya beraspirasikan pencegahan terhadap masyarakat secara keseluruhan. Setiap hukuman yang diperuntukkan oleh Islam akan dilaksanakan di hadapan komuniti muslim yang akan menyaksikannya. Dengan melihat kesakitan yang dialami oleh penjenayah sepanjang proses hukuman, masyarakat Islam akan mengambil iktibar dan pengajaran untuk tidak melakukan jenayah yang sama pada masa akan datang.

Bagi mencapai tujuan ini maka sesetengah jenayah dikenakan hukuman yang keras. Namun demikian realiti pada hari ini membuktikan betapa sukarnya untuk melihat kejayaan pencegahan jenayah melalui hukuman jenayah. Walaupun hukuman keras dikenakan, kadar jenayah pada umumnya semakin bertambah. Menurut para ulama menyifatkan hukuman yang dikenakan kepada penjenayah adalah suatu rahmat. Hal ini kerana ia dapat mewujudkan suasana aman dan selamat di dalam masyarakat. Ianya bukan sahaja menimbulkan rasa serik kepada penjenayah, bahkan juga kepada orang ramai seluruhnya. Hal ini selaras dengan apa yang dinyatakan dalam alQur'an seperti yang bermaksud, "Dan peraturan hukum qisas ini, adalah suatu jaminan hak hidup bagi kamu semua, hai orang-orang yang berpikir, demi menghindarkan adanya pertumpahan darah."

Hal ini bermakna pada hukuman Qisas itu ada keselamatan nyawa. Nyawa (hayat) yang disebutkan dalam ayat ini merujuk kepada keselamatan orang ramai hasil dari pelaksanaan hukuman bunuh balas atau qisas itu. Sehingga apabila hukuman qisas dit- 
erapkan maka negara akan menjadi aman, sebab tidak ramai orang yang berani melakukan jenayah tersebut sebab akibat yang ditimbulkan adalah sama ianya akan dibalas sesuai dengan jenayah yang dilakukan.

\subsection{Hukuman} sebagai

Perwujudan Keadilan Hukuman yang dilaksanakan bertujuan untuk mewujudkan rasa keadilan kepada manusia bagi menjamin kebahagiaan hidup, keadilan dalam menjalankan hukuman sehingga akan menghasilkan kemakmuran dan kedamaian dalam masyarakat. Tujuan 'uqubah dalam Islam untuk menjamin tertegaknya keadilan, perkara ini dapat dilihat dari beberapa sudut diantaranya yaitu: (Yaacob, 2002: 177-197)

1. Setiap hukuman mestilah mempunyai peruntukan dalam Syariah, supaya ia tidak terkeluar dari batasan yang ditentukan oleh Syarak.

2. Syarak mensyaratkan bahawa setiap manusia akan memikul dosanya sendiri, ia tidak boleh ditanggung oleh orang lain.

3. Pembalasan haruslah sesuai dengan kesalahan yang dilakukan.

4. Semua orang akan mendapat persamaan di sisi undangundang, tampa mengira pangkat, kedudukan dan kekayaan.

Diantara ciri-ciri 'uqubah yang dianggap sebagai asas untuk menjamin tertegaknya keadilan ialah: (Yaacob, 2002: 177-197)

1. 'Uqubah mestilah boleh menghalang orang lain daripada melakukan jenayah dengan mengenakan hukuman yang berat, tetapi dalam batas-atas keadilan.

2. Mestilah ada kesesuaian antara 'uqubah dengan jenayah yang dilakukan, hukumnya tidak sesuai haruslah dielakkan.

3. Mestilah mendatangkan kemakmuran dan kesejahteraan dalam masyarakat.

4. Ia mesti dilaksanakan sepenuhnya bagi memastikan tiada sesiapa yang terlepas dari sebarang hukuman di atas kesalahannya.

\subsection{Hukuman sebagai Penghapus} Dosa

Hukuman yang dilaksanakan kepada pesalah di dunia sebagai penghapus dosa dan apabila pesalah yang melakukan jenayah bunuh yang tidak disengaja sehingga ia dimaafkan dan dikenakan diyat maka wajib baginya untuk membayar kaffarah. Kaffarah ini menurut Muhammad Az-Zuhaili berasal dari kata al 
kaflu, yang bermaksud menutupi, oleh kerana ia dapat menutupi kesalahan dan menghapuskannya. (Zuhaili, 2009:371)Dari segi yang lain pula, di antara hikmah di sebalik perlaksanaan undangundang jenayah Islam ialah sebagai "kaffarah" kepada pelakunya. Kaffarah bermaksud sebagai penghapus atau penyucian daripada dosa. Hukuman yang dikenakan ke atas penjenayah yang terbukti bersalah, sebenarnya satu proses penyucian daripada dosa yang ia lakukan. Selain daripada itu, kaffarah bukan sahaja sekadar hukuman penyiksaan, tetapi ia juga adalah penghapus dosa yang dilakukan oleh si pelakunya dan sekaligus bertindak menyelamatkannya daripada di azab oleh Allah Ta'ala kelak di akhirat kerana dosanya yang ia lakukan. (Sabiq, 2009: 256-257)

Kaffarah ini dikenakan bagi kesalahan bunuh dengan niat, hamper sengaja dan tanpa niat. Ia juga dikenakan walaupun pesalah telah digugurkan daripada tuntutan diyat. Kaffarah ini perlu dibayar walaupun pesalah masih kanak-kanak, orang gila atau telah baligh. (al-Khin, 2009:68) Manakala ulama Hanafiah berkata kaffarah tidak wajib dilaksanakan atas anak kecil dan orang gila. Selain daripada itu para ulama Hanafiah dan Malikiah bersepakat bahawa kaffarah itu tidak wajib dil- aksanakan atas orang kafir. (alJazairi, 2011:768-769)

Dalil yang menunjukkan bahawa hukuman daripada Allah Ta'ala itu bertindak sebagai kaffarah adalah sebagaimana yang tersebut dalam Al-Qur'an seperti berikut yang terjemahannya:

"Dan tidak harus sama sekali bagi seseorang mukmin membunuh seorang mukmin yang lain, kecuali dengan tidak sengaja. Dan sesiapa yang membunuh seorang mukmin dengan tidak sengaja, maka (wajiblah ia membayar kaffarah) dengan memerdekakan seorang hamba yang beriman serta membayar "diyat" (denda ganti nyawa) yang diserahkan kepada ahlinya (keluarga simati), kecuali jika mereka sedekahkan (memaafkannya). Tetapi jika ia (yang terbunuh dengan tidak sengaja) dari kaum (kafir) yang memusuhi kamu, sedang ia sendiri beriman, maka (wajiblah sepembunuh membayar kaffarah saja dengan) memerdekakan seorang hamba yang beriman. Dan jika ia (orang yang terbunuh dengan tidak sengaja itu) dari kaum (kafir) yang ada ikatan perjanjian setia diantara kamu dengan mereka, maka wajiblah membayar "diyat" (denda ganti nyawa) kepada keluarganya serta memerdekakan seorang hamba yang beriman. Dalam pada itu, sesiapa yang tidak dapat (mencari hamba yang akan dimerdekakannya), maka hendaklah ia berpuasa dua bulan 
berturut-turut; (hukum yang tersebut) datangnya dari Allah untuk menerima taubat (membersihkan diri kamu). Dan (ingatlah) Allah Maha Mengetahui, lagi Maha Bijaksana". (Q.S. AlNisaa, 92)

Selain daripada hadis dari Wathilah Bin al-Asqa', dia berkata yang artinya: Kami mendatangi Rasulullah Shallallahu 'Alaihi Wasallam (dengan membawa kes) mengenai salah seorang dari kalangan kami yang telah melakukan pembunuhan. Beliau bersabda: "Merdekakanlah seorang hamba sahaya, niscaya kelak Allah akan membebaskan setiap anggota tubuhnya dari api neraka oleh sebab hamba sahaya yang telah dimerdekakannya". (Sabiq, 2009: 260-261)

Kaffarah merupakan
kewajiban bagi pesalah yang
melakukan jenayah pembunuhan
tidak sengaja, untuk membayar
kaffarah yang berupa pembebasan
seorang hamba yang mukmin.
Dengan itu sesiapa yang tidak
memilikinya, ataupun tidak mem-
iliki wang yang melebihi keperlu-
annya untuk membeli hamba
sedemikian serta membebaskann-
ya, ataupun memang tidak kedapa-
tan hamba sama sekali, maka wajib
ke atasnya berpuasa selama dua
bulan berturut-turut sebagai kaf-
farah yang merupakan pertau-
batan untuk membersihkan diri
dari dosa.

Menegakkan keadilan, dengan tujuan setiap kesalahan dibalas dengan balasan yang setimpal tidak lebih dan tidak kurang ini untuk memberi kepuasan kepada mereka yang terkena kejahatan. Selain daripada itu, hukuman juga akan mendidik masyarakat seluruhnya. Ini bertujuan supaya penjenayah akan terdidik dengan hukuman yang di terimanya serta bertaubat, begitu juga masyarakat umum akan dapat pendidikan dari pelaksanaan hukuman tersebut serta mereka merasa takut dan gerun untuk melakukan jenayah. Kemudian melaksanakan hukuman dalam Islam secara adil kepada semua tampa terkecuali, tidak ada perbezaan antara orang yang berpangkat dan yang tidak, antara yang kaya dengan miskin, antara orang kuat dengan orang lemah. Maka dengan ini keunggulan dan keadilan sistem perundangan Islam akan menjadi suatu faktor yang sangat penting dalam menimbulkan keharmonian dan kebahagiaan masyarakat yang menjadi cita-cita semua umat manusia.

\section{KESIMPULAN}

Perundangan dalam Islam adalah berdasarkan kepada Syariat serta panduan daripada Allah SWT. yang telah termaktub dalam alQuran dan juga daripada hadis. Segala-gala yang berkaitan dengan 
kesalahan, hukuman dan peraturan adalah bersandarkan kepada isi kandungan al-Quran dan hadis sebagai panduan. Setiap yang bernyawa pasti memiliki hak masing-masing dan bagi mempertahankan hak-hak tersebut mesti melalui cara yang adil. Sistem perundangan adalah penting supaya mekanisme mempertahankan hakhak tersebut berjalan dengan lancar dan teratur. Keadilan seksama pasti diperoleh melalui perundangan Islam, kerana konsep perundangan Islam membantu umatnya menyelesaikan masalah kehidupan secara adil.

Undang-undang Islam merupakan peraturan yang telah ditetapkan oleh Allah S.WT. untuk dilaksanakan dalam sesebuah negara bagi menjamin keadilan dan keselamatan ummah. Segala perkara yang dilarang dalam Islam dikategorikan sebagai jenayah. Jenayah iaitu melakukan sesuatu perkara yang ditegah oleh Allah S.WT. atau meninggalkan sesuatu perkara yang disuruh olehNya. Jenayah dalam Islam dibahagi kepada hudud, qisas diyat dan ta'zir.

Matlamat daripada dikenakannya hukuman hudud, qisas dan ta'zir adalah untuk melindungi masyarakat daripada bahaya jenayah dan mencegah sebelum ia berlaku. Kemudian untuk memperbaiki penjenayah dan membetulkan penyelewengan. Hal ini dapat dilihat daripada kesan yang ditinggalkan oleh hukuman ke atas penjenayah yang memberi pengajaran, memperbaiki dan menghalang seseorang daripada melakukan jenayah. Selain daripada itu hukuman juga untuk membersihkan dosa penjenayah dan menyelamatkannya daripada azab di akhirat.

Peranan undang-undang jenayah Islam adalah untuk mewujudkan keamanan dan kesejahteraan dalam masyarakat. Undang-undang jenayah Islam juga dalam menjatuhkan hukuman secara adil dan saksama. Misalnya sebagai contoh di mana orang yang membunuh akan dihukum bunuh balas, sehingga menyebabkan warisnya berpuas hati dan hilang perasaan dendam. Selain daripada itu hukuman jenayah Islam yang kemas dan tegas menyebabkan penjenayah dan orang ramai takut dan gerun untuk mengulangi jenayah. Akhirnya kehidupan masyarakat aman dan sejahtera. Hukuman jenayah Islam juga mengandungi unsur-unsur pendidikan kepada penjenayah dan orang ramai. Hukuman yang dikenakan mendorong seseorang penjenayah bertaubat dan menyesali kesalahan yang dilakukannya. Dengan ini jenayah akan berkurangan dalam masyarakat. 


\section{DAFTAR PUSTAKA}

Al Asqalani. I. H. 2009. Fathul Baari Penjelasan Kitab: Syarah Shahih Al Bukhari. Jakarta: Pustaka Azzam.

al-Bakri. Z. M. 2009. Al-Fiqh AlManhaji Madhab Al-Syafie Jilid Enam, Bangi-Selangor Malaysia: Darul Syakir Enterprise.

Al-Jazairi. A. R. 2011 Fiqh 4 Mazhab Juzuk 4 dan 5, Malaysia : Perniagaan Jahabersa.

al-Jazairi. A. R. 2011. Fiqh 4 Mazhab Juzuk 4 dan 5. Malayasia: Perniagaan Jahabersa.

Al-Zuhaili. W. 2005. Fiqh \& Perundangan Islam, Jilid VI. Kuala Lumpur: Dewan Bahasa dan Pustaka.

Al-Zuhaily. M. M. 2012. Al-Mu'tamad Dalam Fiqh Madhab Syafi'I Jilid 9 Jihad dan Undang-Undang Jenayah, Malaysia : Persekutuan Seruan Islam (Jam'iah).

Audah. A. Q. 1994. 'al-Tasyri' al-Jinaiy al-Islami. Jilid 1. Beirud: Muassasah al-Risalah.

Az-Zuhaili. M. 2009. AL-Mu'tamad Fiqah Imam Syafi'I, Jilid 5. Malaysia. Berlian Publications SDN BHD, Puchong, Selangor D.E.

Bahnasy. A. F. $1969 . \quad$ Al-Siyasah alJina'iyyah fi al-Shari'ah alIslamiyyah, Kaherah: Maktab Ammar. Kaherah.
Otman. M. S. A. 2000. Nizam Uqubah dalam Islam dan Pelaksanaannya di Malaysia : Tinjauan Kepada Perundangan Islam, Kuala Lumpur: Institut Kafahaman Islam Malaysia (IKIM).

Rahman. M. S. A. 2000. Uqubah Menurut Undang-Undang Jenayah Islam : Tinjauan Kepada Perundangan Islam. Kuala Lumpur: Institut Kafahaman Islam Malaysia (IKIM).

Rawi. Z. F M. 2007. Syariah Perundangan Islam (Siri Asas Islam dan Pengibadatan). Malaysia: Associated Educational Distributors.

Sabiq. S. 2008. Fiqhus Sunnah (Fiqh Sunnah). Jakarta: Pena Pundi Aksara, Jakarta.

Samuri. M. A. 2012. "Teori Pencegahan Sebagai Justifikasi Hukuman: Analisis Perbandingan antara Perundangan Sivil dan Islam". Jurnal Islamiyyat, Volume 34. BangiMalaysia: Fakulti Pengajian Islam UKM.

Zuhaili. W. 2011. Figih Islam waAdillatuhu (Fiqh dan Perundangan Islam), Jilid VII. Jakarta: Gema Insani \& Darul Fikir. 2011. 